\title{
EFFECT OF PRISM HEIGHT ON STRENGTH OF REINFORCED HOLLOW CONCRETE BLOCK MASONRY
}

\author{
Shivaraj kumar H Y ${ }^{1}$, Renuka Devi M V ${ }^{2}$, Sandeep ${ }^{3}$, Manjunath $S^{4}$, Somanath M $B^{5}$ \\ ${ }^{I}$ Mtech Student PG-Structural Engineering, Dept of Civil Engg, RVCE \\ ${ }^{2}$ Associate professor, Dept of Civil Engg, RVCE \\ ${ }^{3}$ Mtech Student PG-Structural Engineering 2011-2013, Dept of Civil Engg, RVCE \\ ${ }^{4}$ Assistant professor, Dept of Civil Engg, RVCE \\ ${ }^{5}$ Ph-D Research Scholar, Dept of Civil Engg, RVCE
}

\begin{abstract}
Reinforcing masonry is a suitable means of improving masonry performance in compressive and tensile strength in order to exploit masonry to its full potential. Experimental study has been carried out to investigate the effect of reinforced masonry prisms on its behavior in compression and effect of slenderness on the same. Mechanical properties of hollow blocks, mortar and grout were investigated. Compressions testing of both unreinforced and reinforced masonry prisms were carried out. From the results, advantage of reinforcing masonry and the effect of slenderness ratio is highlighted.
\end{abstract}

Keywords: Structural masonry, Hollow concrete block, prism, grout, slenderness ratio

\section{INTORDUCTION}

Practice of masonry block work in buildings and civil engineering structures has a long history going back to centuries. Reinforced masonry also not being younger than masonry dating back to $1813-1825$, adopted to increase the load bearing capacity of walls[1]. Due to the improvement in the masonry materials, construction skills and reinforcement techniques have improved the masonry construction from massive load bearing structures to competitive and economical with a bonus of thermal comforts.

Masonry buildings when subjected to lateral loads were found to have earthquake related problems due to insufficient shear and flexural capacity. With the development of reinforced masonry by incorporating steel to provide with flexural and tensile resistance. Especially for reinforcing hollow blocks steel can be introduced to resist in-plane seismic forces of earthquake. In the past few decades different ways of reinforcing masonry techniques have been proposed, ensuring ductility and energy dissipating capacity. The masonry systems depend on various parameters like geometric shapes and material of masonry unit, mortar, grout and amount of steel and its detailing. Masonry has a promising future being the most important construction material for buildings, schools and other structures in the 21 st century.

In this experimental program effect of reinforcing hollow masonry prisms on compression capacity is studied by testing both unreinforced masonry prisms and reinforced masonry prisms. In addition a comparison is made on the effect of slenderness on the compressive strength of both unreinforced masonry prisms and reinforced masonry prisms.

\section{EXPERIMENTAL PROGRAMME}

Experimental investigation were carried out to arrive at the following aspects:

(i) Compressive strength and stress-strain characteristics of hollow concrete block, mortar and grout.

(ii) Compressive strength and stress-strain characteristics of Unreinforced Masonry (URM) and Reinforced Masonry (RM ) prisms.

\subsection{Hollow Concrete Blocks}

For the proposed study hollow blocks of best available strength were adopted from local standard manufacturers of size $400 \times 200 \times 190 \mathrm{~mm}$. The basic mechanical properties such as dimensionality, dry density, water absorption were conducted as per IS 2185 Part 1-1979[2], IRA was conducted as per ASTM C67[3] and compression and stress-strain characteristics were obtained by testing them in compression testing machine. Mean values of dry density, water absorption, IRA and compression were $2365.95 \mathrm{Kg} / \mathrm{m}^{3}, 3.2 \%, 0.705 \%$ and $6.57 \mathrm{MPa}$ respectively. The Young's modulus at $30 \%$ of peak stress was found to be $14393.5 \mathrm{MPa}$.

\subsection{Cement-Sand Mortar}

Cement-sand mortar of 1:6 volume mix was adopted in this investigation. Grade 53 ordinary port land cement conforming to IS 2250-1981[4] and river sand from a local source was 
used. Consistency of mortar was obtained by performing flow table test according to IS 5512-1969[5] and water-cement ratio of 1.26 was adopted for $100 \%$ flow. Compressive strength of mortar was obtained by testing mortar cubes of $5 \mathrm{~cm}$ and the mean compressive strength obtained was $6.3 \mathrm{MPa}$. The modulus of mortar was taken from stress-strain relationship obtained by compression testing of prisms of $150 \times 150 \times 300$ and the young's modulus at $30 \%$ peak stress was found to be $10222.54 \mathrm{MPa}$.

\subsection{Grout}

Grout is a filler material used to fill the cells in hollow blocks to increase its strength and hold the steel in its desirable position. Grout adopted for masonry prisms was of high slump mixture of cement, aggregate, water. To arrive at the watercement ratio for a desirable slump of 200 to $250 \mathrm{~mm}$ [6], slump test was carried out. M20 grade concrete of maximum size of aggregate $12.5 \mathrm{~mm}$, with a slump of $210 \mathrm{~mm}$ was used as grout with water-cement ratio of 0.75 as obtained in slump test. The compressive strength of grout was obtained by compression test of grout concrete cube of $150 \mathrm{~mm}$. The mean compressive strength was obtained as $26 \mathrm{MPa}$. The modulus of grout was taken from stress-strain relationship obtained by compression testing of cylinders of 150 diameter x 300 and the young`s modulus at $30 \%$ peak stress was found to be $29527 \mathrm{MPa}$.

\subsection{Reinforcement}

Reinforcement in masonry is adopted to increase shear and tensile stress resisting capacity, axial load carrying capacity for various load conditions and inducing ductility to resist seismic loads. In this investigation reinforcement was provided as per guidelines of IITK-GSDMA[7]. Providing with $0.56 \%$ steel, Grade Fe 415 reinforcing bars of $12 \mathrm{~mm}$ diameter was provided at all four corner of the block as longitudinal reinforcement and supported by stirrups of $8 \mathrm{~mm}$ diameter holding all four bars as lateral reinforcement.

\subsection{Compressive Strength of Masonry Prisms}

Masonry prisms are obtained when the hollow blocks are stack bonded one above the other. In this experimental programme compressive strength of stack bonded masonry prism of 5 block height were cast. Both URM and RM prisms of hollow concrete blocks with $10 \mathrm{~mm}$ mortar joint were cast and cured under moist gunny bags.

\section{CASTING AND TESTING}

Compressive strength of masonry was determined by testing the stack bonded masonry prisms. Five block height stack bonded masonry prism were casted using $200 \mathrm{~mm}$ hollow concrete blocks and cement-sand mortar(1:6) as shown in fig 3(a). Prisms of size $400 \times 200 \times 990 \mathrm{~mm}$ with a joint thickness of $10 \mathrm{~mm}$ were used. Further prisms were prepared with reinforcement for examining the influence of reinforcement on masonry compressive strength. Fe-415 grade reinforcing bars of diameter $12 \mathrm{~mm}$ and $8 \mathrm{~mm}$ were used and 53 grade of ordinary Portland cement was used as shown in fig 3(e).

Testing of four of each URM and RM prisms were carried out on Testing floor with $1000 \mathrm{KN}$ capacity hydraulic jack, $100 \mathrm{~mm}$ bearing plate and demec gauge of least count of 0.001 for measuring deformation across the mortar joint.

Testing of URM prisms was done as shown in fig 3(b) and the crack, failure pattern was observed as shown in fig 3(c),3(d).

Testing of RM prisms was done as shown in fig 3(f) and the crack, failure pattern was observed as shown in fig $3(\mathrm{~g})$.

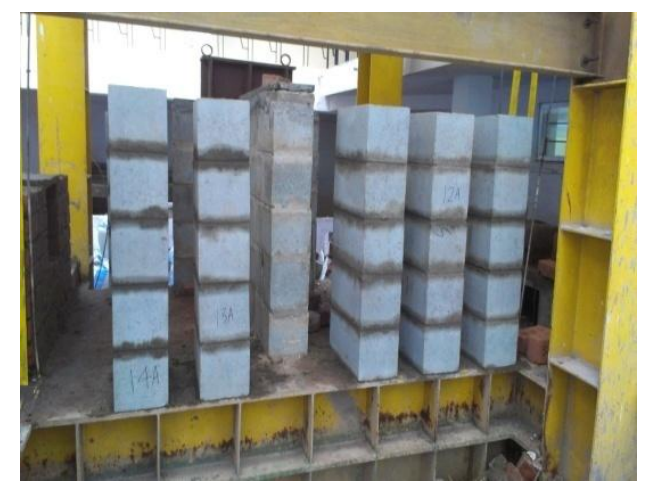

Fig 3(a) Cast prisms on Testing frame

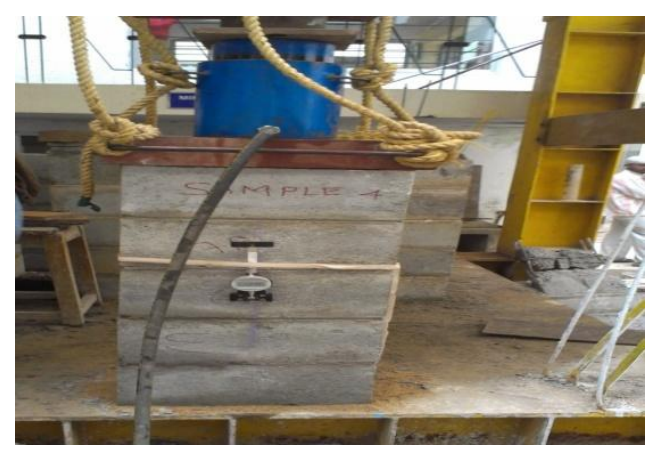

Fig 3(b) Testing setup

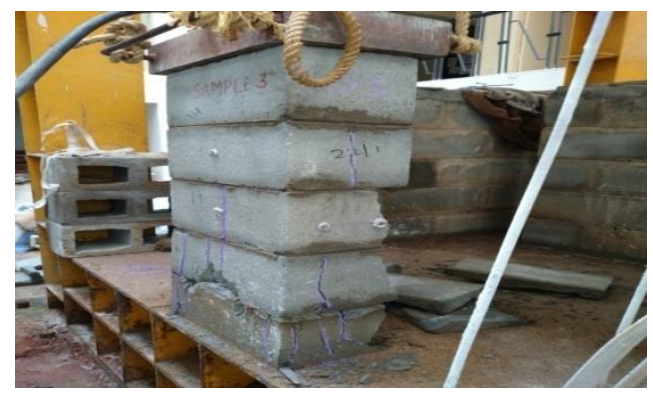

3(c) crack pattern 


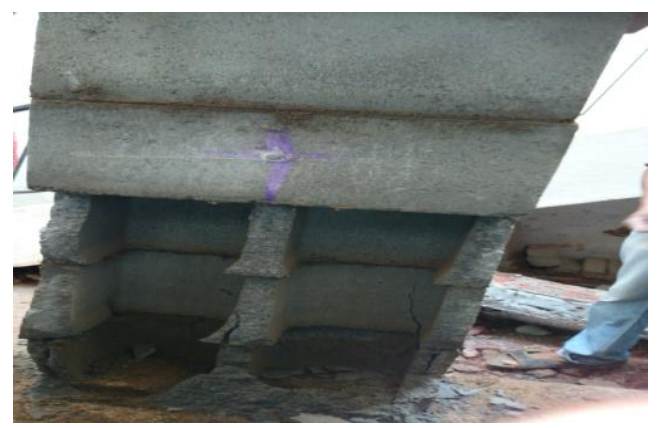

Fig 3(d) failure pattern

Observation: Crack initiated from the bottom block and propagated to $3^{\text {rd }}$ block. Material crushing was observed at 3 $\& 4^{\text {th }}$ mortar joints from Top

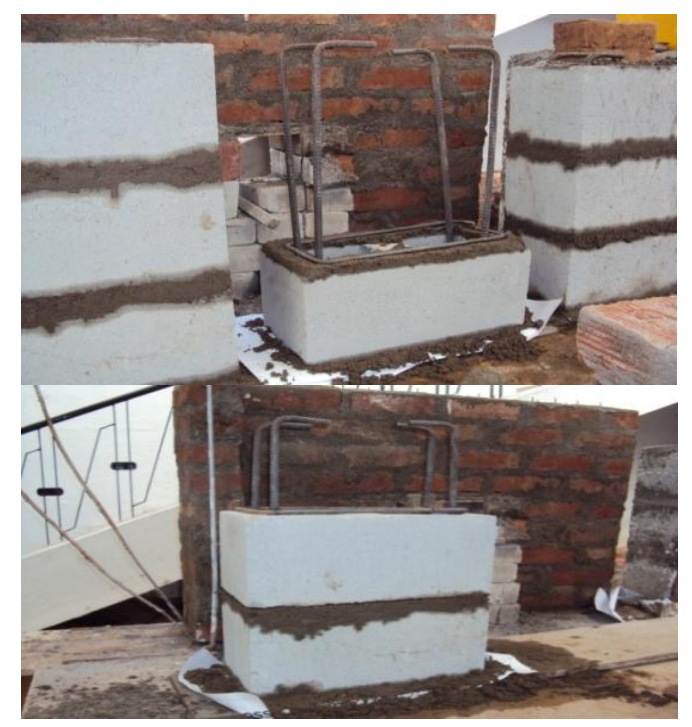

Fig 3(e) Casting procedure

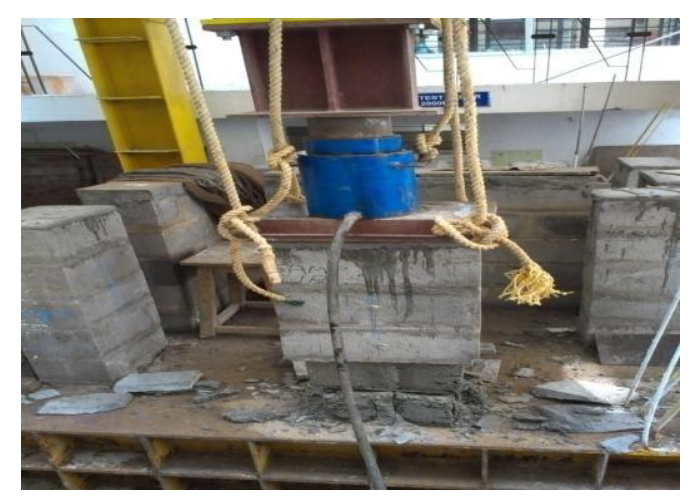

Fig 3(f) Test setup and crack pattern

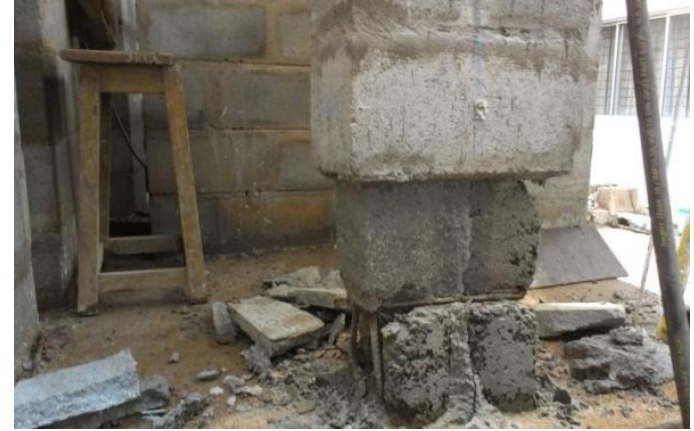

Fig 3(g) Spalling of block material

Observation: Crack initiated from the bottom block and propagated to $2^{\text {nd }}$ block. Material crushing and block spalling out was observed $3^{\text {rd }} \& 4^{\text {rd }}$ mortar joints from Top

\section{RESULTS AND DISCUSSION}

The mean compressive strength of URM and RM prisms were obtained to be 4.21 and $8.02 \mathrm{MPa}$ respectively as shown in table 1.

The modulus of URM and RM prisms was obtained from their respective stress-strain relationship. The modulus of URM and RM prism were found to be 4545 and $10199 \mathrm{MPa}$ respectively shown in plot 1 and plot 2 . The above results shows that reinforcing the masonry prisms with $0.56 \%$ steel the increase in compressive strength was found to be $90.5 \%$ of that of URM.

The results also shows that the increase in modulus of elasticity is 2.24 times of URM for RM prism.

Effect of slenderness on the compressive strength was studied by comparing the results of 3 block height prism[8] and 5 block height prism. Comparison is shown in table 2. From the results it is observed that the compressive strength of masonry reduces with increase in slenderness ratio. 
Table 1

\begin{tabular}{|c|c|c|c|}
\hline Particulars & No. of samples & Mean compressive stress, MPa & Coefficient of variation, $\%$ \\
\hline $\begin{array}{c}\text { Unreinforced masonry prism } \\
\text { URM }\end{array}$ & 4 & 4.21 & 18.6 \\
\hline Reinforced masonry prism RM & 4 & 8.02 & 22.3 \\
\hline
\end{tabular}

Table 2

\begin{tabular}{|c|c|c|c|c|c|c|}
\hline \multirow[t]{2}{*}{$\begin{array}{l}\text { Type of } \\
\text { Masonry }\end{array}$} & \multirow[t]{2}{*}{$\begin{array}{c}\text { Slenderness ratio } \\
(\mathrm{h} / \mathrm{t})\end{array}$} & \multirow[t]{2}{*}{$\begin{array}{c}\text { Mean compressive } \\
\text { stress } \\
\text { MPa }\end{array}$} & \multicolumn{2}{|c|}{ Correction factors (CF) } & \multicolumn{2}{|c|}{$\begin{array}{c}\text { Corrected } \\
\text { Mean Compressive stress } \\
\text { MPa }\end{array}$} \\
\hline & & & $\begin{array}{c}\text { IS:1905-1987 } \\
\text { (CF) [9] }\end{array}$ & $\begin{array}{c}\text { ASTM } \\
\text { C1314 } \\
\text { (CF) [10] }\end{array}$ & IS:1905-1987 & $\begin{array}{l}\text { ASTM } \\
\text { C1314 }\end{array}$ \\
\hline URM & 3.02 & 4.49 & 1.2 & 1.07 & 5.33 & 4.8 \\
\hline RM & 3.07 & 8.3 & 1.23 & 1.09 & 10.21 & 9.08 \\
\hline URM & 4.87 & 4.21 & 1.36 & 1.210 & 5.72 & 5.09 \\
\hline RM & 4.9 & 8.02 & 1.363 & 1.213 & 10.93 & 9.72 \\
\hline
\end{tabular}

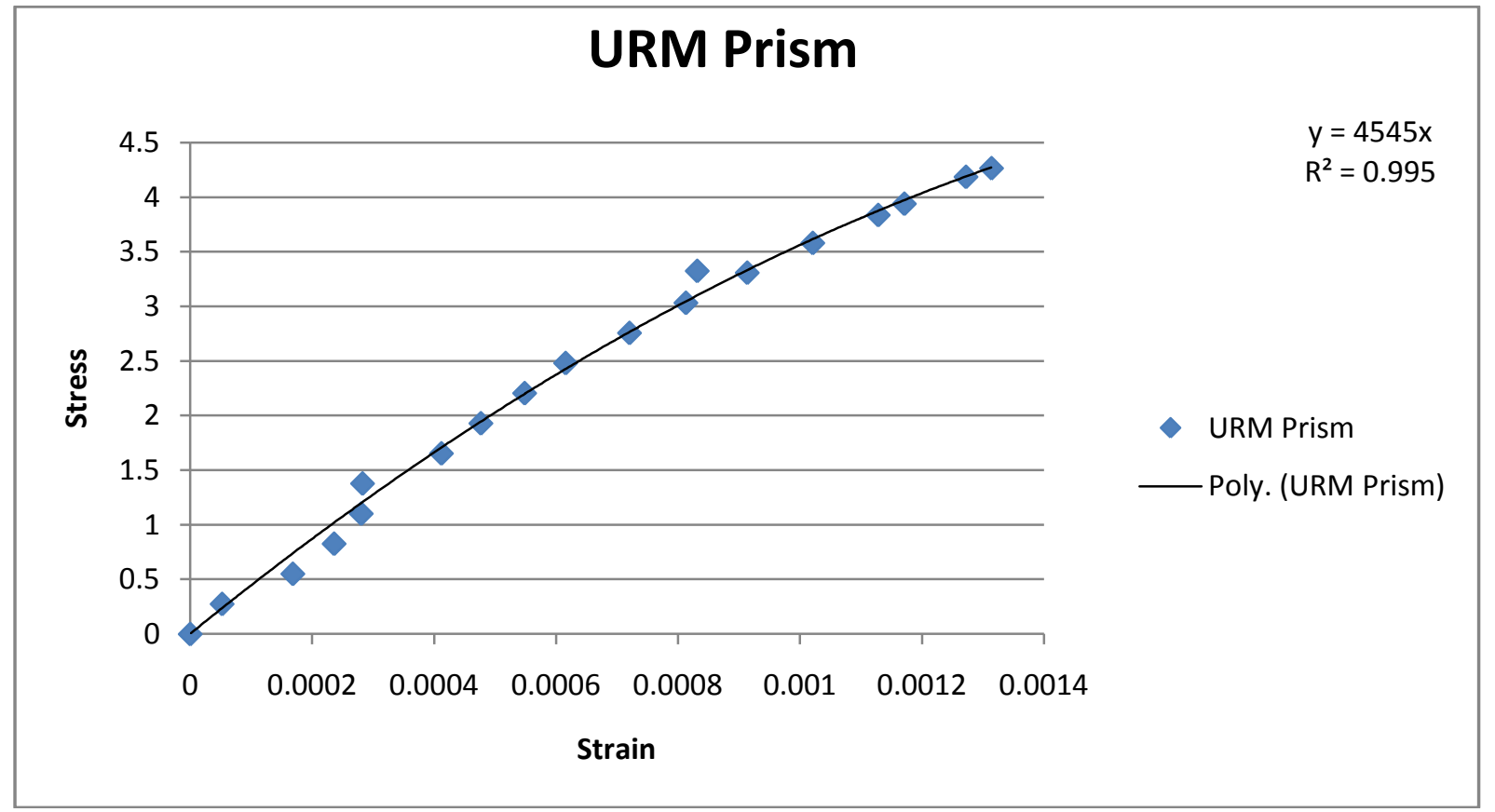

Plot 1 Stress Vs Strain curve for Unreinforced masonry prism 


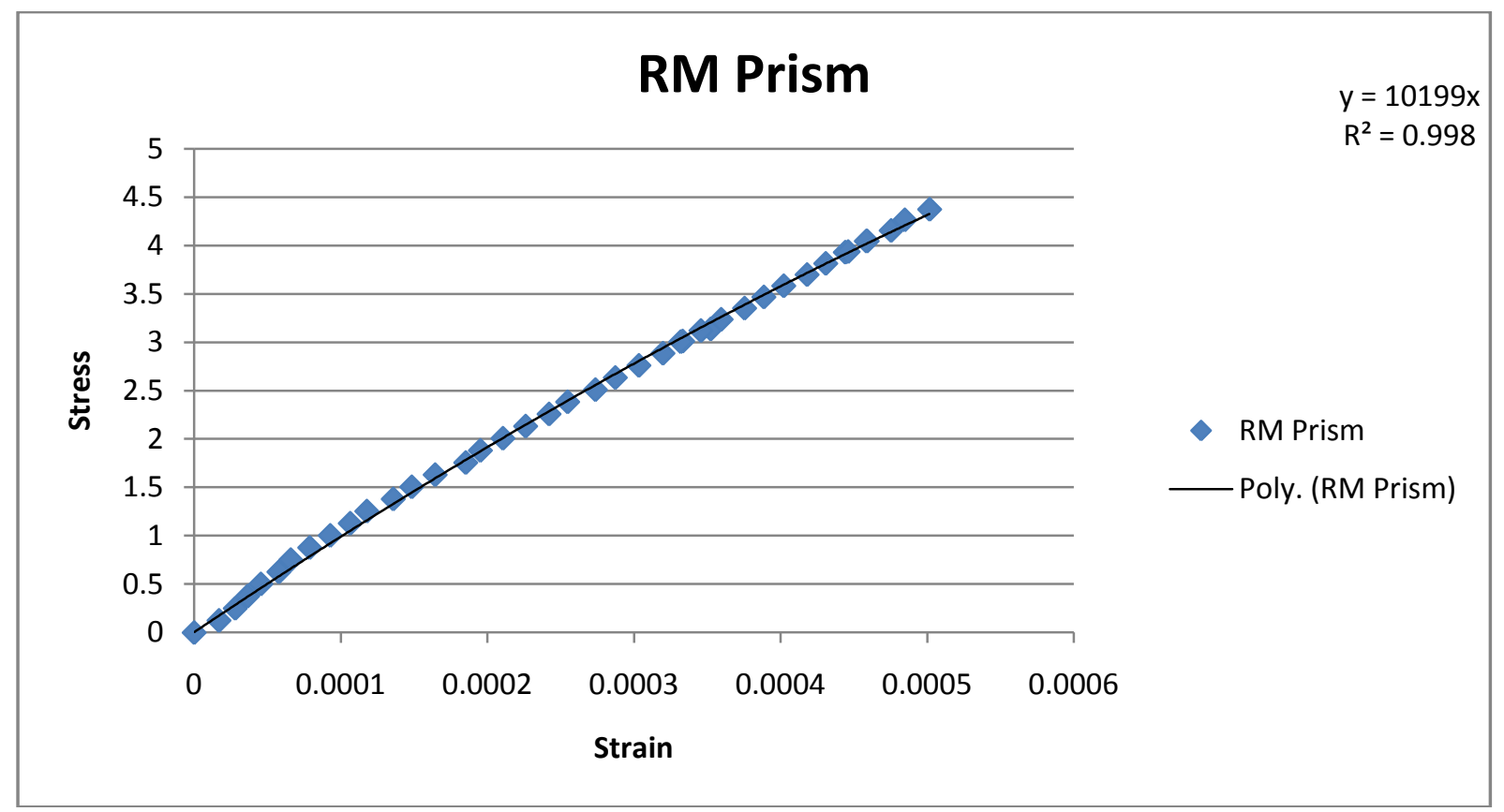

Plot 2 Stress Vs Strain curve for Reinforced masonry prism

\section{CONCLUSIONS AND REMARKS}

1. Reinforcing of masonry prisms increases the axial compression load capacity, encouraging to be used in load bearing structures.

2. Effect of increase in slenderness ratio on compression strength should result in reduction of compression strength. The investigation showed that the reduction was only marginal of 0.3 MPa. A possible explanation for this result could be because of variation in the mechanical properties of the masonry components such as compressive strength of unit blocks, mortar, grout, quality of river sand etc.. Which cannot be humanly controlled.

3. Masonry behavior being complex involving several variation factors, it is recommended that more investigation involving 3,4,5 block height masonry prisms is needed to be carried out to arrive at a fair conclusion.

\section{REFERENCES}

[1]. Anita Fódi and István Bódi, Basics of reinforced masonry, Concrete Structures, pp.69-77, 2011.

[2]. IS: 2185 (part 1), Specification for concrete masonry units, BIS Publication, New Delhi.1979.

[3]. ASTM C 67, Standard test methods for sampling and testing, 1994.

[4]. IS: 2250, Code of practice for Masonry mortars. BIS Publication, New Delhi, 1981.

[5]. IS: 5512, Indian standard specification for flow table for use in tests of hydraulic cements and pozzolanic materials, BIS Publication, New Delhi, 1969.
[6]. Robert G. Drysdale and Ahmad A. Hamid (2008), Masonry structures behavior and design, Third edition, McMaster University, Hamilton, Ontario.2008

[7]. IITK-GADMA guidelines for structural use of reinforced masonry, National Information Center for Earthquake Engineering, Indian Institute of Technology Kanpur,2006

[8]. Sandeep, M V Renukadevi, S Manjunath, Somanath, Influence of reinforcement on the behavior of hollow block masonry prism under compression- an experimental and analytical approach, International journal of research in engineering and technology, pp 106-110,Nov 2013.

[9]. IS: 1905 "Code of practice for structural use of unreinforced masonry". BIS Publication, New Delhi, 1987.

[10]. ASTM C 1314, "Standard Test Method for Compressive Strength of Masonry Prisms.”2003. 